\title{
Representasi Perempuan Berhijab dan Budaya Konsumen dalam Iklan Wardah Exclusive Series in London
}

\author{
Ersa Nur Oktavia (Penulis Korespondensi) \\ Program Studi Ilmu Komunikasi, Universitas Muhammadiyah Yogyakarta, Indonesia \\ ersanuroktaviaa@gmail.com \\ Pinto Rizqan Palma Putra \\ Program Studi Ilmu Komunikasi, Universitas Muhammadiyah Yogyakarta, Indonesia \\ pintorz27@gmail.com \\ Sabrina \\ Program Studi Ilmu Komunikasi, Universitas Muhammadiyah Yogyakarta, Indonesia \\ sb.rn263@gmail.com \\ Diserahkan: 30 April 2020; Direvisi: 09 Oktober 2020; Diterima: 10 Oktober 2020
}

\begin{abstract}
Wardah cosmetic products are one of the many cosmetic products that use television as a medium to promote their products. Wardah also proved that all activities were still carried out using Muslim clothing and hijab, but the use of Muslim clothing and hijab was adjusted to the type of activity carried out. This is evidenced by the various types of Muslim clothing and hijab models that are worn when carrying out several different activities. For example, this Wardah Exclusive Series In London ad represents the modern lifestyle of Muslim women. The Wardah Exclusive Series In London ad shows the woman wearing the hijab very comfortable on her journey around the City of London. Through the semiotic method, it is found that women who wear hijab are also proven to be active and stylish in carrying out various activities.
\end{abstract}

Keywords: Cosmetics, Representation, Muslim Women

\section{Abstrak}

Produk kosmetik Wardah adalah salah satu dari sekian banyak produk komestik yang menggunakan televisi sebagai media untuk mempromosikan produk mereka. Wardah juga membuktikan bahwa semua aktivitas masih dilakukan menggunakan pakaian muslim dan hijab, tetapi penggunaan pakaian muslim dan hijab disesuaikan dengan jenis kegiatan yang dilakukan. Hal ini dibuktikan melalui berbagai macam jenis pakaian muslim dan model hijab yang dipakai saat melakukan beberapa kegiatan berbeda. Misalnya Iklan Wardah Exclusive Series In London ini merepresentasi gaya hidup modern wanita muslim. Iklan Wardah Exclusive Series In London menunjukkan wanita berhijab tersebut sangat nyaman dalam perjalanannya mengelilingi Kota London. Melalui metode semiotik ditemukan bahwa perempuan berhijab juga terbukti dapat aktif dan stylish dalam melakukan berbagai kegiatan.

Kata Kunci: Kosmetik, Representasi, Wanita Muslim

\section{PENDAHULUAN}

Iklan adalah suatu bentuk komunikasi yang digunakan untuk menyampaikan suatu informasi atau pesan tentang suatu produk, layanan, ataupun informasi lainnya. Gaya hidup masyarakat yang modern saat ini tidak lepas dari media massa yang sifatnya mengikuti perkembangan yang ada, hal ini dikarenakan media massa menjadi alat/media penyampaian pesan kepada khalayak luas. Hampir semua orang menggunakan televisi sebagai media untuk memperoleh informasi. Dari berbagai macam program siaran yang ditampilkan di televisi, iklan merupakan salah satu siaran yang cukup banyak dilihat audiens. 
Kita dapat menjumpai iklan dimanapun dan kapanpun karena iklan ada dimana-mana. Iklan dalam bisnis media pada dasarnya merupakan sumber pemasukan dan keuntungan dari penjualan produk media itu sendiri. Di televisi, setiap programnya didukung oleh iklan berbagai produk barang maupun jasa. Periklanan adalah suatu proses komunikasi massa yang melibatkan sponsor tertentu, yakni pemasang iklan yang membayar jasa sebuah media atas penyiaran iklannya, misalnya melalui program siaran televisi. Iklan televisi pada umumnya lebih mudah mempengaruhi pemirsa karena setiap hari ditayangkan, bahkan setiap acara televisi selalu diselingi dengan iklan. Dengan begitu suatu produk yang secara terus- menerus ditayangkan akan meninggalkan bekas pada ingatan pemirsa. Banyak pengiklan memandang televisi sebagai media yang paling efektif untuk menyampaikan pesan-pesan komersialnya, selain itu juga memiliki pengaruh yang kuat untuk mempengaruhi persepsi khalayak sasaran.

Kebanyakan masyarakat meluangkan waktunya di muka televisi, sebagai sumber berita, hiburan, dan sarana pendidikan. Calon pembeli lebih "percaya" pada perusahaan yang mengiklankan produknya di televisi dari pada yang tidak sama sekali. Ini adalah cerminan bonafiditas pengiklan. Selain itu, penayangan iklan di televisi sering kali bersentuhan dengan aspek moralitas masyarakat dan pengelabuhan persepsi publik. Produk yang ditawarkan melalui iklan di media televisi sebagian mengandung unsur inspiratif, yang secara persuasif mempengaruhi masyarakat untuk membeli produk tersebut. Terdapat beberapa iklan yang memiliki konsep berbeda dan menarik, salah satunya adalah iklan kosmetik. Iklan kosmetik menjadi salah satu iklan yang cukup menarik karena memiliki tandatanda maupun makna yang bisa menarik perempuan untuk mempercayai dan membelinya.

Hal itu menuntut para pembuat iklan kosmetik berpikir lebih keras dalam usahanya menampilkan sebuah iklan yang dapat mempresentasikan perempuan dan menjadi kebutuhan setiap perempuan untuk tampil cantik. Setiap iklan kosmetik selalu memiliki faktor metafora dalam menyampaikan pesannya yang mengandung tanda dan makna tersembunyi. Begitu pula dengan tampilan iklan Wardah Exclusive Series memuat representasi perempuan muslimah cantik, yang menjadi idaman dan dambaan perempuan- perempuan saat ini. Secara tampilan visual, iklan wardah tersebut menampilkan sosok perempuan cantik yang sedang melakukan perjalanan di benua Eropa tepatnya di London, Inggris. Dewi Sandra sebagai model perempuan muslimah cantik sejalan dengan konsep wardah yang merupakan produk kosmetik yang halal dan ditujukan untuk kaum perempuan muslimah. Setiap iklan kosmetik berupaya menampilkan sosok perempuan cantik dengan versi masing-masing, tak terkecuali iklan Wardah Exclusive Series. Perempuan memiliki bagian-bagian tubuh yang dijadikan objek kecantikan dan mempunyai makna sosial bagi masyarakat, beberapa bagian tubuh tersebut salah satunya adalah wajah, bagian fisik manusia yang unik, lunak dan bersifat publik. Sebagai bagian tubuh yang dapat dilihat dengan jelas, makna kondisi dari wajah akan terlihat oleh masyarakat umum mulai dari jenis warna kulit yang berwarna putih atau hitam, kulit yang berminyak atau kering, hingga ada atau tidaknya jerawat dan noda yang melekat pada wajah.

Pada penelitian yang dilakukan oleh Rahmawati (2017) menemukan bahwa iklan shampo Sunsilk Hijab Refresh versi Carla Rizki merepresentasikan citra perempuan berhijab ini ditandai dengan aktivitas sehari-hari yang dilakukan dan ekspresi wajah dari model iklan tersebut. Berbeda dengan penelitian yang dilakukan oleh Zulfa (2017). Iklan Wardah dipilih menjadi subjek penelitian karena kerap menampilkan sosok muslimah dalam beberapa iklannya, baik di media cetak maupun elektronik. Tampilan muslimah tersebut dianggap menjadi pelengkap dari label halal yang diusung Wardah, agar lebih membuat calon pembeli merasa yakin akan kehalalan yang terkandung dalam kosmetik tersebut. Dengan label halal yang erat kaitannya dengan keislaman itu, Wardah juga menjadi perhatian banyak orang termasuk akademisi. Hal tersebut terbukti dari banyaknya penelitian berupa skripsi dan jurnal ilmiah yang membahas cerita- cerita yang dibangun oleh produsen Wardah. Itulah yang mendasari 
keinginan penulis untuk meneliti iklan Wardah menggunakan metode semiotika Charles Sanders Peirce. Iklan Wardah tersebut tidak hanya membentuk citra mereknya yang mengusung label halal, namun juga membentuk citra muslimah yang membintangi iklannya.

\section{KERANGKA TEORI}

\section{SEMIOTIKA}

Semiotika (Bahasa Inggris: semiotic) berasal dari Bahasa Yunani, yaitu semieon yang berarti tanda. Semiotika diperkenalkan oleh Ferdinand De Saussure (1857-1913). Untuk memahami gagasan Saussure, kita perlu memahami tentang penanda dan petanda, serta langue dan parole. Pertama, tanda (sign) terdiri dari dua aspek, yaitu penanda (signifiant), dan petanda (signified). Penanda bisa dimengerti sebagai bentuk/wujud fisik. Penanda dapat berupa suara, gambar, huruf, visual dan sejenisnya. Sementara petanda adalah konsep atau arti dari apa yang ditandai. Relasinya antara keduanya bersifat "diada-adakan" (arbitrary), yang berarti tidak ada relasi yang sifatnya alamiah antara penanda dan petanda. Tetapi demikian, relasi yang bersifat "diada- adakan" terikat oleh konvensi atau struktur. Penjelasan selanjutnya akan menjelaskan tentang hal ini. Secara etimologis, Saussure menuturkan bahwa semiotika sebagai ilmu yang mengkaji tentang tanda sebagai bagian dari kehidupan sosial (Piliang, 2003). Selanjutnya Saussure, semiotika kemudian dielaborasi sebagai hubungan tripartit yakni tanda (sign) yang merupakan gabungan dari penanda (signifier) dan petanda (signified) (Fiske dan Hartley, 1996).Kedua, langue dan parole. Langue adalah abstraksi dan artikulasi bahasa pada tingkat sosial budaya, sedangkan parole adalah ekspresi bahasa pada tingkat individu. Agar lebih mudah memahaminya, langue dapat kita sebut sebagai sistem bahasa yang berlaku, sedangkan parole adalah bagaimana individu berbahasa dalam sistem tersebut.

Roland Barthes melanjutkan pemikiran Saussure dengan memberi pengkajian pada interaksi antara teks dengan pengalaman personal dan kultural penggunanya. Interaksi antara konvensi dalam teks dengan konvensi yang dialami dan diharapkan oleh penggunanya. Gagasan Barthes ini dikenal dengan tatanan penandaan (order of signification), yang mencakup primary signification atau denotasi (makna sebenarnya sesuai kamus) dan secondary signification atau konotasi (makna ganda yang lahir dari pengalaman kultural dan personal). Makna konotasi inilah yang kemudian berkembang menjadi mitos. Dalam penelitian ini, penulis berusaha melakukan analisis semiotika, mulai dari primary signification sampai secondary signification pada iklan Wardah versi Exclusive Series. Tataran denotasi menghasilkan makna yang eksplisit, langsung, dan pasti. Dalam Semiologi Barthes, denotasi merupakan sistem signifasi tingkat kedua. Denotasi dapat dikatakan merupakan makna objektif yang tetap, sedangkan konotasi merupakan makna subjektif dan bervariasi (Nurmaida, 2020).

\section{REPRESENTASI}

Istilah representasi secara lebih luas mengacu pada penggambaran kelompok kelompok dan institusi sosial (Burton, 2000). Sebuah representasi selalu berhubungan dengan stereotip, dimana seseorang dinilai dengan apa yang digambarkan dengan tampilan fisik secara diskriptif. Hal ini dipertegas Fairclough bahwa representasi yaitu melihat bagaimana peristiwa, orang, kelompok, situasi, keadaan, atau apa pun ditampilkan dan digambarkan dalam teks (Eriyanto, 2001). Namun lebih jauh penggambaran tersebut mengandung nilai maupun makna tertentu yang terdapat dari penggambaran yang dimunculkan oleh media. Media yang dimaksud yaitu iklan. Dimana iklan dijadikan sebuah medium dalam menyampaikan pesan yang secara sengaja diciptakan untuk mencapai target sasarannya. Seperti yang ditegaskan Adorno dan Horkheimer bahwa media cenderung bekerja menurut sistem yang seragam dan monolitik (Tester, 2009). 
Dalam bukunya yang berjudul Representation: Cultural Representation and Pignifying Practices, Stuart Hall mendefinisikan representasi sebagai berikut.

"Representations connects meaning and which meaning and language to culture. Representation is also an essential part of the process by which meaning is produced and exchanged between members of culture" (Hall, 2003).

Sebuah makna diproduksi dan dipertukarkan antar anggota masyarakat melalui representasi. Singkatnya, representasi bisa dikatakan sebagai salah satu cara untuk memproduksi sebuah makna. Sistem representasi terbentuk atas komponen penting, yaitu konsep dalam pikiran dan bahasa. Kedua komponen representasi bekerja dan terdapat relasi pula antara kedua komponen tersebut. Namun jika tanpa bahasa, makna tidak akan dapat dikomunikasikan. Misalnya, kita mengetahui konsep sisir (alat untuk merapikan rambut). Hal tersebut menandakan bahwa, untuk membuat sebuah pemahaman yang hampir sama, diperlukan produksi dan pertukaran makna dengan baik yang dilakukan oleh kelompok yang memiliki latar belakang pengetahuan yang sama. Menurut Stuart Hall (2003) konsep representasi mengacu pada hal berikut ini.

"Members of the same culture must share sets of concepts, images and ideas which enable them to think and feel about the world, and thus to interpret the world, in roughly similar ways. They must share, broadly speaking, the same 'cultural codes'. In this sense, thinking and feeling are themselves 'systems of representation" (Hall, 2003).

Menurut Hall, berpikir dan merasa merupakan sistem representasi. Kedua hal tersebut juga berfungsi untuk memaknai suatu hal. Oleh sebab itu, diperlukan latar belakang pemahaman yang sama terhadap konsep, gambar dan ide untuk memaknai sesuatu. Dalam budaya atau kelompok masyarakat yang berlainan, pemaknaan sesuatu dapat sangat berbeda karena adanya cara tersendiri yang dimiliki oleh masing-masing budaya atau kelompok masyarakat untuk memaknai sesuatu.

Sebuah makna yang diproduksi oleh kelompok masyarakat tidak akan dapat dipahami oleh kelompok masyarakat lain yang memiliki pemahaman tidak sama terhadap kode-kode budaya tertentu. Suatu makna terlihat seolah-olah natural dan tidak dapat diubah karena dipahami dengan tegas oleh manusia. Melalui sistem representasi dan verifikasi kode, dikonstruksilah sebuah makna. Hal tersebutlah yang membuat adanya kesamaan pemahaman dalam suatu kelompok budaya, yang telah melewati proses konvensi secara sosial. Contohnya, kita mengomunikasikan suatu hal (misalnya kue) kepada orang lain dengan menggunakan kata-kata. Hal ini senada dengan kata-kata yang telah disepakati dalam masyarakat kita untuk memaknai suatu konsep. Contohnya, kata rumah yang merupakan kode dengan arti (dalam pikiran kita) tempat berlindung atau berkumpul bersama keluarga. Dengan demikian, melalui kode terbangun korelasi antara sistem konseptual yang ada dalam pikiran kita dengan sistem bahasa yang kita gunakan.

Contoh di atas menunjukkan bahwa proses untuk memproduksi makna dari konsep melalui tanda disebut representasi. Munculnya sistem representasi tersebut memungkinkan adanya proses produksi sebuah makna. Namun, latar belakang pengetahuan dan pemahaman suatu kelompok sosial terhadap suatu tanda juga berpengaruh dalam proses pemaknaan tersebut. Kesamaan pengalaman untuk memaknai sesuatu dengan cara yang hampir sama merupakan hal yang harus dimiliki suatu kelompok. 


\section{BUDAYA KONSUMEN}

Bagi masyarakat konsumen, saat ini hampir tidak ada ruang dan waktu tersisa untuk menghindari diri dari serbuan berbagai informasi yang berurusan dengan kegiatan konsumsi. Di rumah, kantor, ataupun tempat-tempat lain masyarakat tidak henti-hentinya disajikan berbagai informasi yang menstimulasi konsumsi melalui iklan di televisi, koran, ataupun majalah. Fenomena masyarakat konsumsi tersebut, yang telah melanda sebagian besar wilayah dunia, saat ini juga sudah terjadi pada masyarakat Indonesia, terutama di masyarakat perkotaan. Menurut Piliang (2004), fenomena yang menonjol dalam masyarakat Indonesia saat ini yang menyertai kemajuan ekonomi adalah berkembangnya budaya konsumsi yang ditandai dengan berkembangnya gaya hidup.

Perkembangan televisi global sebagai bangunan bisnis utama telah menempatkan budaya konsumen, iklan berbasis visual, di barisan depan aktivitasnya (Mattelart dan Mattelart dalam Barker, 1992). Televisi menduduki posisi sentral dalam produksi dan reproduksi budaya promosi yang terfokus pada pemakaian citra visual untuk menciptakan merk dengan nilai tambah atau tanda komoditas. Berkembangnya gaya hidup masyarakat perkotaan tersebut, satu sisi dapat menjadi pertanda positif meningkatnya kesejahteraan hidup masyarakat kota. Hal ini dibuktikan melalui peningkatan kegiatan konsumsi dipandang sebagai efek dari naiknya penghasilan dan taraf hidup masyarakat. Namun di sisi lain, fenomena tersebut juga bisa dikatakan sebagai pertanda kemunduran rasionalitas masyarakat, yang mana konsumsi dianggap sebagai faktor yang menyebabkan hilangnya kritisme masyarakat terhadap berbagai hal yang vital bagi kehidupan, kebijakan pemerintah maupun fenomena hidup lainnya.

Pengaruh budaya terhadap perilaku konsumen, dapat dilihat dari produk dan jasa memainkan peranan yang sangat penting dalam mempengaruhi budaya karena produk mampu membawa pesan makna budaya. Dimana makna budaya tersebut nantinya akan dipindahkan ke produk dan jasa, dan produk kemudian dipindahkan ke konsumen. Makna budaya atau makna simbolik yang telah melekat kepada produk akan dipindahkan kepada konsumen dalam bentuk pemilikan produk (possession ritual), pertukaran (exchange), pemakaian (grooming ritual), pembuangan (divestment ritual).

Pengaruh budaya terhadap perilaku konsumen, dapat dilihat dari produk dan jasa memainkan peranan yang sangat penting dalam mempengaruhi budaya karena produk mampu membawa pesan makna budaya. Dimana makna budaya tersebut nantinya akan dipindahkan ke produk dan jasa, dan produk kemudian dipindahkan ke konsumen. Makna budaya atau makna simbolik yang telah melekat kepada produk akan dipindahkan kepada konsumen dalam bentuk pemilikan produk (possession ritual), pertukaran (exchange), pemakaian (grooming ritual), pembuangan (divestment ritual).

\section{METODE PENELITIAN}

Jenis penelitian yang digunakan dalam penelitian ini adalah deskriptif kualitatif dengan paradigma kritis. Secara lebih operasional, penelitian ini menggunakan metode semiotika untuk menganalisis obyek penelitian. Obyek penelitian dalam penelitian ini adalah iklan Wardah versi Exclusive Series In London tahun 2018 berdurasi 30 (tiga puluh) detik dan berformat iklan video. Obyek penelitian ini dianalisis dengan menggunakan analisis semiotika Roland Barthes yang mengembangkan pemikiran dari Ferdinand De Saussure.

\section{HASIL DAN PEMBAHASAN}

Makna denotatif adalah makna asli, makna asal, atau makna sebenarnya yang dimiliki oleh sebuah leksem. Kalau makna denotatif mengacu pada makna asli atau makna sebenarnya dari sebuah kata atau leksem, maka makna konotatif adalah makna lain yang "ditambahkan" pada makna denotatif tadi yang berhubungan dengan nilai rasa dari orang atau kelompok orang yang menggunakan kata tersebut. konotasi yang negatif adalah nilai rasa atau perasaan tidak enak bila mendengar kata itu. Konotasi 
positif adah nilai yang mengenakan; orang akan senang kalau dikatakan ramping. Sebaliknya, kata kerempeng, yang sebenarnya juga bersinonim dengan kata kurus dan ramping itu, mempunyai konotasi yang negatif, nilai rasa yang tidak mengenakan; orang akan merasa tidak enak kalau dikatakan tubuhnya kerempeng. Berdasarkan atas apa yang sudah disampaikan dalam pendahuluan, maka berikutnya akan dipaparkan mengenai temuan dan pembahasan penelitian. Berikut adalah potongan scene dari iklan Wardah Exclusive Series.

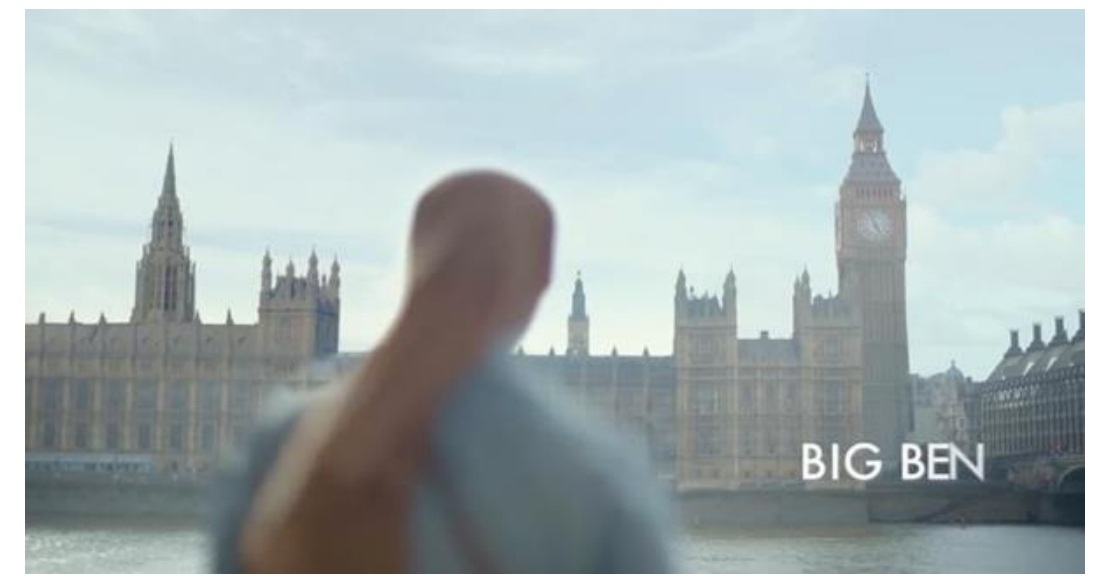

Gambar 1. Tampilan visual pada scene 1, detik 1 (Youtube, 2017)

Denotasi pada scene kedua dari iklan Wardah Exclusive Series ini yaitu seorang wanita yang sedang menikmati keindahan pemandangan jam Big Ben. Konotasi dari scene tersebut adalah menyampaikan bahwa iklan tersebut diambil latar di London, dengan menunjukkan tempat yang terkenal dan sangat populer sehingga siapapun yang melihatnya maka pasti tahu bahwa tempat itu adalah di London.

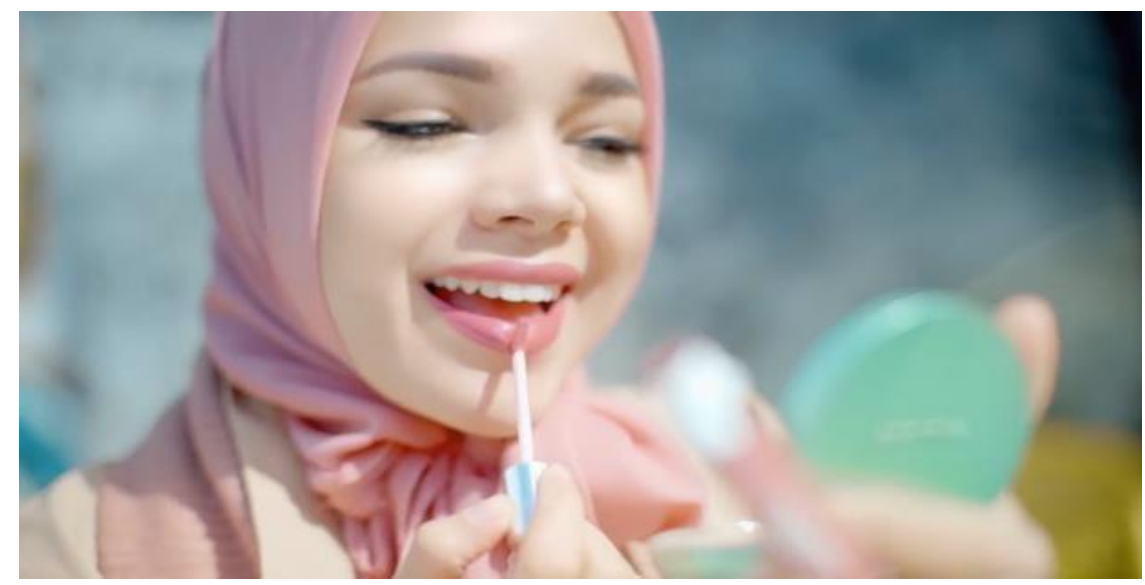

Gambar 2. Tampilan visual pada scene 2, detik 4 (Youtube, 2017)

Denotasi pada scene kedua dari iklan Wardah Exclusive Series ini jika dilihat dari signified (petanda) yaitu seorang wanita cantik yang sedang menggunakan sebuah kosmetik agar terlihat lebih cantik. Menggunakan hijab, berkulit putih, dan selalu menampilkan senyum yang manis. Signifier (penanda) kecantikan wajah, kosmetik sebagai penunjang kecantikan. Konotasi dari scene tersebut adalah seorang wanita cantik yang menggunakan hijab serta selalu menebarkan senyumnya yang manis dan menggunakan kosmetik Wardah Exclusive Series sebagai salah satu kosmetik halal yang ada di 
Indonesia. Dengan menggunakan kosmetik Wardah Exclusive Series membuat wanita tampil dengan sosok mandiri, cerdas, supel/ramah, stylish/fashionable dan modern.
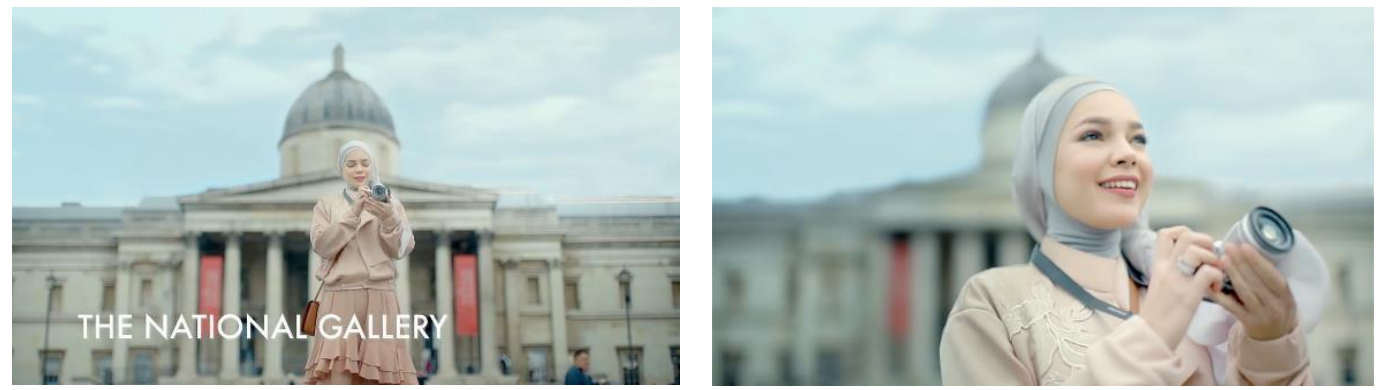

Gambar 3. Tampilan visual pada scene 3, detik 7 (Youtube, 2017)

Denotasi pada scene kedua dari iklan Wardah Exclusive Series ini yaitu seorang wanita yang sedang berfoto-foto disalah satu destinasi wisata yang berada di London. Konotasi dari scene tersebut adalah seorang wanita berhijab yang menyukai fotografi biasanya memiliki pandangan detail dan selalu mengabadikan momen-momen yang sering terlewatkan oleh banyak orang. Ditandai dengan wanita tersebut tentunya memiliki kemampuan tinggi sebab pandai menggunakan kamera dalam artian wanita yang cerdas, selanjutnya wanita itu juga termasuk wanita modern sebab bisa menggunakan teknologi khususnya kamera serta pandai memadupadankan busana dengan gaya tertentu.

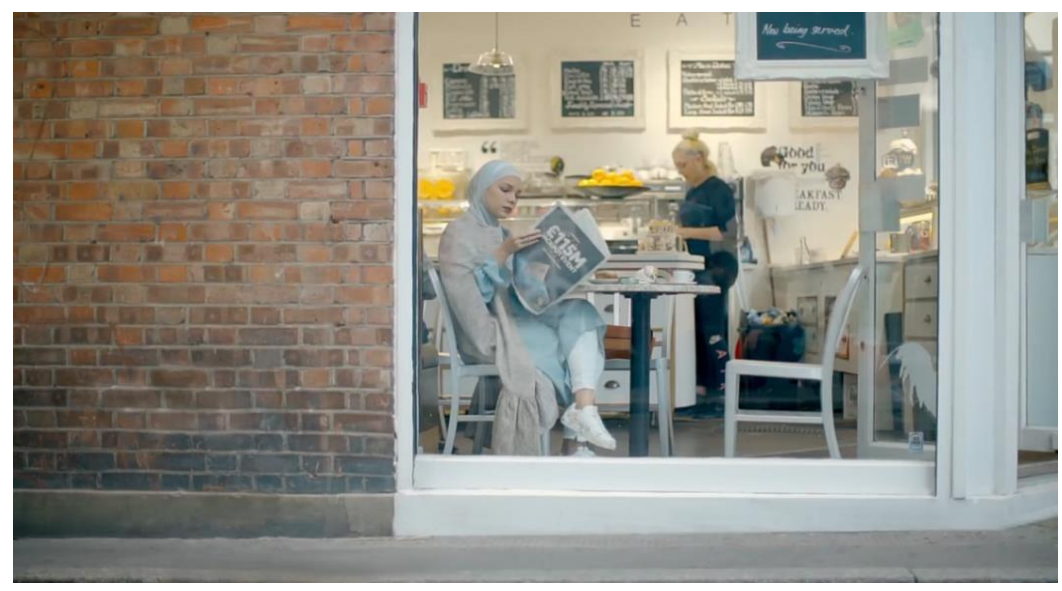

Gambar 4. Tampilan visual dalam scene 4, detik 11 (Youtube, 2017)

Pada scene ke empat denotasi pada scene tersebut yaitu seorang wanita yang sedang duduk membaca surat kabar di sebuah kafe dan duduk didekat jendela kaca. Konotasi dari scene ini adalah seseorang wanita yang menggunakan hijab sedang membaca surat kabar di sebuah kafe pada sore hari dengan tanpa adanya rasa khawatir dengan sinar matahari duduk didekat jendela kaca, karena ia adalah wanita yang menggunakan kosmetik halal, sehingga tidak adanya rasa khawatir atau rasa takut pada pancaran sinar ultraviolet matahari yang membuat kulit cantiknya menjadi lebih gelap karena ia menggunakan kosmetik Wardah yang dapat melindungi kulitnya dari pancaran sinar ultraviolet matahari. 


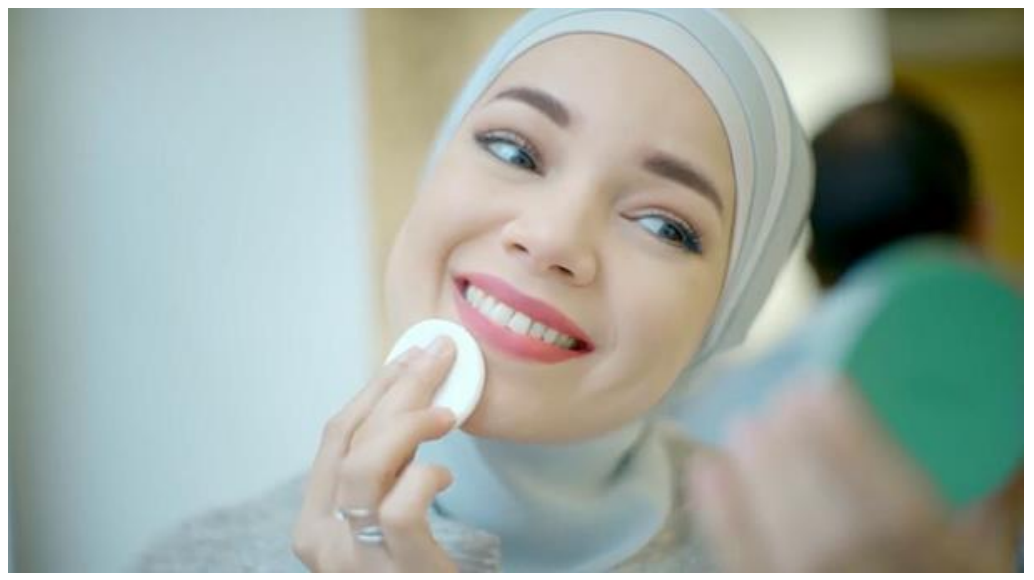

Gambar 5. Tampilan visual scene 5, detik 12 (Youtube, 2017)

Pada scene kedua dari iklan Wardah Exclusive Series ini terdapat denotasi yaitu seorang wanita cantik yang tersenyum memakai sebuah kosmetik agar terlihat lebih cantik dan wajah yang lembut. Menggunakan hijab, berkulit putih, dan selalu menampilkan senyum yang manis. Konotasi dari scene tersebut adalah seorang wanita cantik yang menggunakan hijab serta selalu menebarkan senyumnya yang manis dan menggunakan kosmetik wardah sebagai salah satu kosmetik halal yang ada di Indonesia. Wardah bisa dikatakan sebagai kosmetik yang mampu melindungi wajah seseorang agar tetap terlihat lembut.

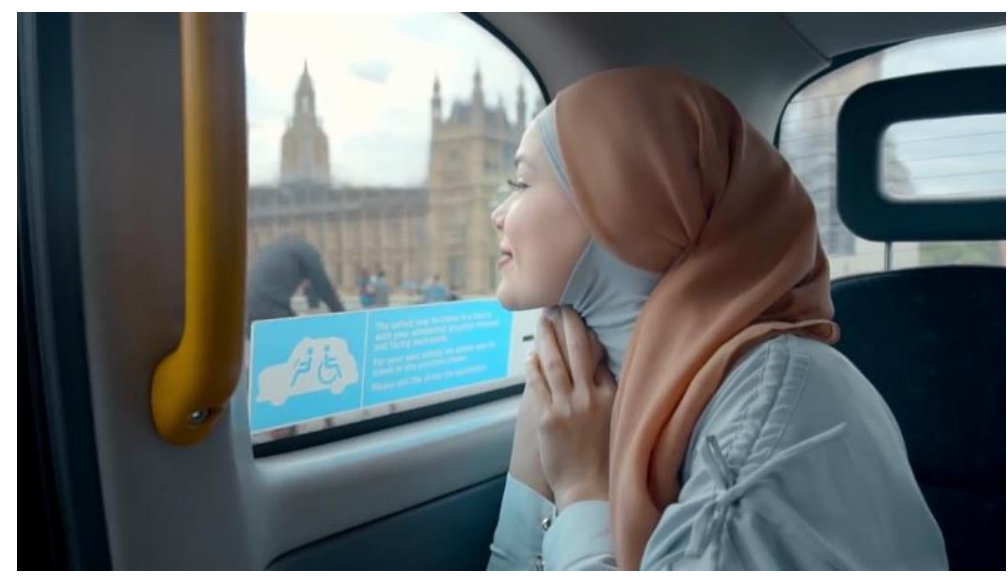

Gambar 6. Tampilan visual scene 6, detik 14 (Youtube, 2017)

Pada scene ke 6 dari iklan Wardah Exclusive Series ini denotasinya jika dilihat dari signified (petanda) adalah adanya seorang wanita yang menggunakan hijab sedang menikmati keindahan kota London dari dalam taksi yang mencerminkan wisatawan. Sedangkan signifier (penanda) yaitu suasana kota dengan bangunan ala Eropa klasik di siang hari. Konotasi dari scene ini seorang wanita biasanya menghindari cuaca yang kurang bersahabat dengan kulit mereka, salah satunya adalah pada siang hari. Karena para wanita menganggap bahwa dengan beradanya mereka di luar rumah ketika siang terik maka kulit mereka terbakar sinar matahari yang menjadikan kulit halus mereka menjadi hitam dan tidak terlihat cantik. Namun, nyatanya pada scene ini wanita mampu menghilangkan pemikiran tersebut. Ketakutan itu dapat dihilangkan karena wanita tersebut menggunakan kosmetik Wardah yang menggunakan 
bahan alami serta halal yang menjadikan kulit mereka dapat terlindungi oleh sinar matahari. Sehingga kosmetik Wardah mampu menjadi inspirasi cantik bagi wanita Indonesia.
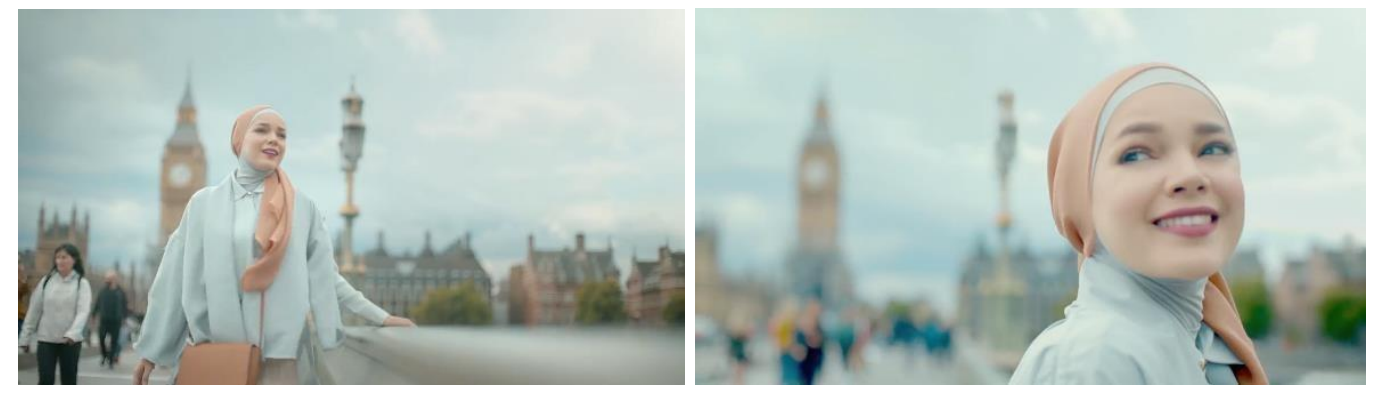

Gambar 7. Tampilan visual pada scene 7, detik 16 (Youtube, 2017)

Makna denotasi pada scene ini adalah seorang wanita berhijab yang sedang berjalan di Westminster Bridge itu dengan latar belakang Big Ben dan Istana Westminster, tempat ini merupakan salah satu spot foto terbaik di London.Makna konotasi pada scene ini wanita berhijab juga dapat tampil modern dan stylish saat sedang travelling.
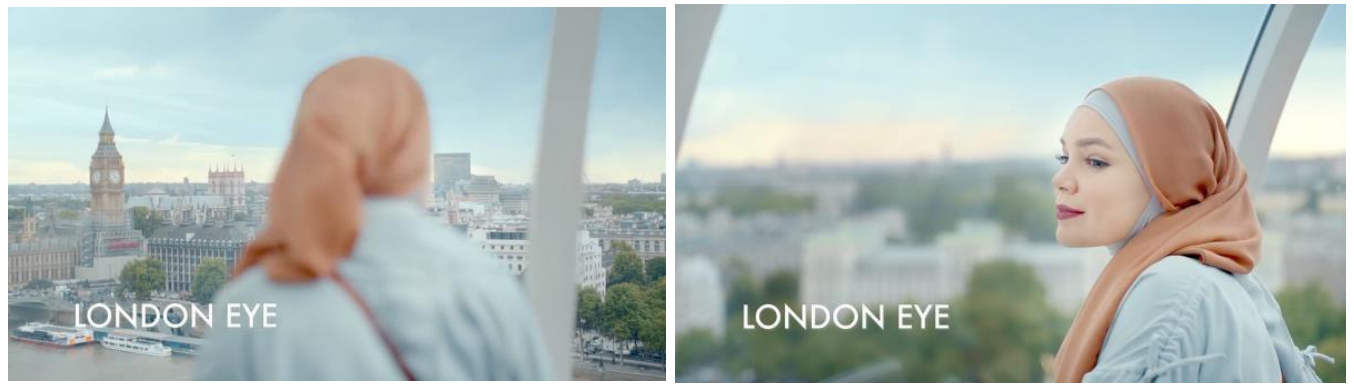

Gambar 8. Tampilan visual pada scene 8, Detik 19 (Youtube, 2017)

Makna denotasi pada scene ini adalah seorang wanita berhijab yang sedang berada di London Eye untuk melihat keindahan Kota London dari atas. Makna konotasi pada scene ini adalah melihat pemandangan Kota London pada saat sang raja siang muncul adalah cara terbaik dan akan lebih indah jika kita sedang berada di atas London Eye, begitu juga definisi cantik, yang akan lebih indah jika dilihat dari sisi yang berbeda. 


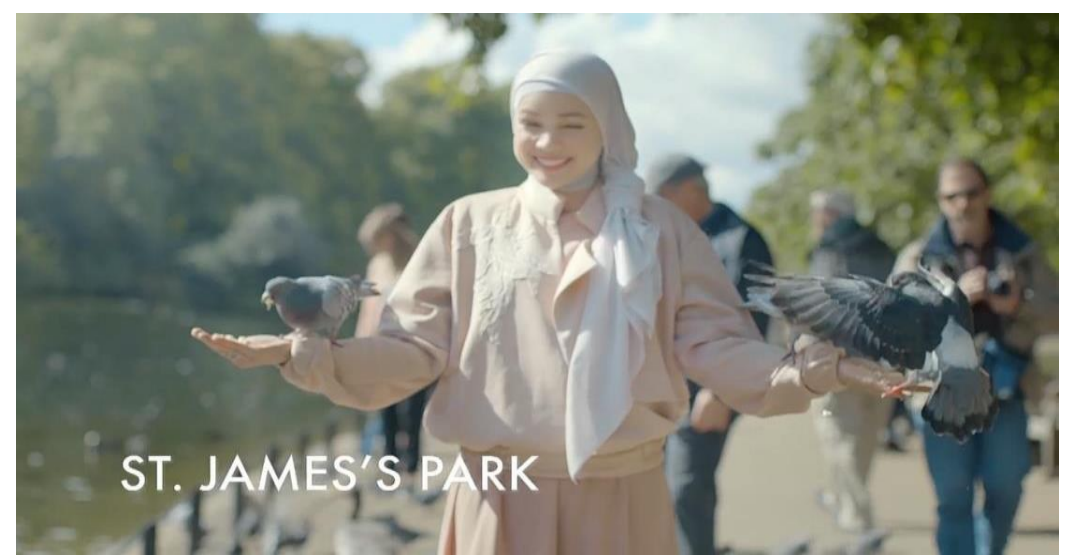

Gambar 9. Tampilan visual pada scene 9, detik 22 (Youtube, 2017)

Makna denotasi pada scene ini adalah seorang wanita berhijab yang sedang tersenyum dan sedang berada di taman yang banyak sekali burung dimana tempat itu dapat memberikan kebahagiaan sederhana untuk orang-orang yang sudah penat dengan hiruk pikuk Kota London. Makna konotasi pada scene ini adalah seorang wanita berhijab akan terlihat lebih cantik jika dirinya selalu rendah hati dan dapat membahagiakan dirinya sendiri dan orang lain jika dirinya menggunakan kosmetik yang memberikan inspirasi bukan hanya untuk dirinya tetap juga pada orang lain, serta akan selalu memberikan senyuman kepada orang lain.

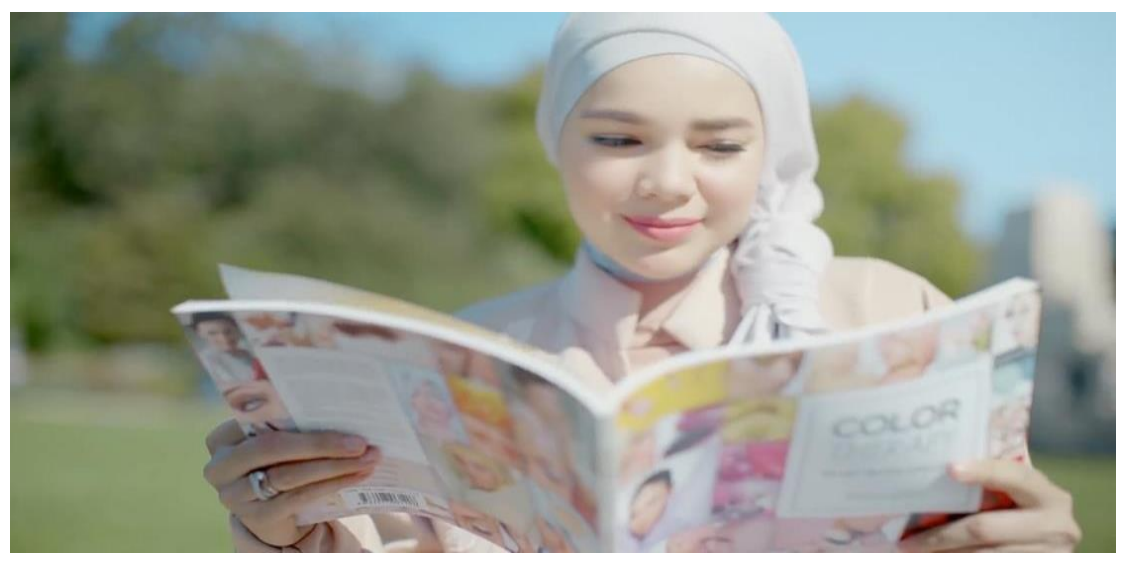

Gambar 10. Tampilan Visual Pada Scene 10, Detik 25 (Youtube, 2017)

Makna denotasi pada scene ini adalah seorang wanita berhijab yang sedang membaca majalah di salah satu taman yang berada di Kota London. Makna konotasi pada scene ini seorang wanita kutu buku akan terlihat lebih cantik jika dirinya tidak hanya mengetahui tentang kosmetik tapi juga banyak mengetahui pengetahuan dan informasi umum.

\section{KESIMPULAN}

Setelah menguraikan dan menjelaskan apa yang ditemukan dalam iklan Wardah Exclusive Series In London, maka terdapat kesimpulan bahwa representasi citra muslimah yang terdapat dalam iklan tersebut menggambarkan sosok muslimah yang modern. Namun, modernitas seorang muslimah dalam iklan tersebut hanya ditunjukkan melalui kegiatannya di Kota London. Selain itu, iklan tersebut juga menampilkan kesan mewah kehidupan seorang muslimah, yang ditandai dengan kesenangan memanjakan diri sendiri dan kepuasan dalam mengonsumsi jasa yang ekslusif pada tempat wisata. 
Tidak hanya itu, representasi citra muslimah dalam iklan tersebut juga memperkuat stereotip yang beredar di masyarakat. Stereotip tersebut menyebutkan bahwa kecantikan wanita hanyalah dilihat dari keindahan wajah dan fisiknya saja. Pada akhirnya, produsen Wardah dalam hal ini terjebak oleh anggapan-anggapan yang menyatakan bahwa cantik hanya sekadar fisik. Padahal sebuah kecantikan juga dapat terlihat dari bagaimana seorang wanita berperan dalam sebuah lingkungan masyarakat. Sebagai kosmetik yang kerap memasukkan unsur-unsur agama dalam memproduksi iklannya, Wardah tidak melihat esensi lain dalam diri wanita yang dapat diangkat untuk memperkuat citra muslimah. Artinya, iklan tersebut kembali mengonstruksi pikiran masyarakat dengan anggapan bahwa kecantikan wajah adalah hal paling penting yang harus dinomorsatukan oleh wanita, sekalipun ia seorang muslimah.

\section{PERSANTUNAN}

Terima kasih kepada Dr. Fajar Junaedi yang telah membimbing proses riset dalam mata kuliah Kajian Kritis Iklan di Program Studi Ilmu Komunikasi UMY, selama satu semester genap tahun akademik 2019/2020 yang menghasilkan luaran berupa artikel ini.

\section{REFERENSI}

Alwasilah, A. C. (1993). Linguistik: Suatu Pengantar. Bandung: Angkasa

Amstrong, G., \& Philip, K. (2002). Dasar-dasar Pemasaran. Jakarta: Prenhalindo.

Burton, G. (2000). Membincangkan Televisi. Yogyakarta: Jalasutra.

Eriyanto. (2001). Analisis Wacana. Yogyakarta: PT. LkiS

Hall, S. (2003). Representation: Cultural Representation and Signifying Practices. London: Sage Publication.

Martha, D. S. (2015). Perilaku Konsumtif Mahasiswi Yang Berstatus Sales Promotion Girl (SPG).

Paradigma, 3(1).

Nurmaida, M., Kamaludin, M,. \& Risnawati, R. (2020). Representasi Nilai-nilai Moral dalam Novel

"Assalamualikum Calon Imam" (Analisis Semiotika Roland Barthes terhadap Tokoh Dokter

Alif). Jurnal Audiens, 1(1), 1-8.

Piliang, Y. A. (2004). Dunia yang dilipat: Tamasya Melampaui Batas-Batas Kebudayaan. Bandung: Jalasutra. Tester, K.(2009). Immortalitas Media. Yogyakarta: Juxtapose.

Youtube.com. (14 Desember 2017). Dewi Sandra - Wardah TVC in London. Diakses dari https://www.youtube.com/watch?v=sJCTV5NleVg 